\title{
Responses of Soil Microorganisms and Enzymatic Activities to Azoxystrobin in Cambisol
}

\author{
Fenghua Wang ${ }^{1-3^{*}}$, Xiaoying Li ${ }^{1}$, Lusheng Zhu ${ }^{1-3^{* *}}$, Zhongkun Du${ }^{1}$, Cheng Zhang ${ }^{1}$, \\ Jun Wang ${ }^{1}$, Jinhua Wang ${ }^{1}$, Dongdong Lv ${ }^{1}$ \\ ${ }^{1}$ College of Resources and the Environment, Shandong Agricultural University, Taian, Shandong, China \\ ${ }^{2}$ National Engineering Laboratory for Efficient Utilization of Soil and Fertilizer Resources, Taian, Shandong, China \\ ${ }^{3}$ Key Laboratory of Agricultural Environment in Universities of Shandong, Shandong, China
}

Received: 30 September 2017

Accepted: 8 December 2017

\begin{abstract}
Azoxystrobin has been largely applied as a kind of new strobilurin fungicide in recent years. Knowledge about the impact of the fungicide on soil biochemical properties is critical for understanding its effect on soil health. The effects of different doses of azoxystrobin $\left(0,0.1,1,10 \mathrm{mg} \cdot \mathrm{kg}^{-1}\right)$ on cultivable soil microbial population, soil enzymatic activities, and soil respiration in Cambisol were investigated under laboratory incubation. These soil properties were determined after treatments of 7, 14, 21, and 28 days. The results indicated that azoxystrobin applications inhibited soil respiration, the populations of bacteria and actinomycetes, and dehydrogenase activity. However, catalase activity was activated as an effect of azoxystrobin application. Meanwhile, the treatment had no significant impact on fungi population and protease activity compared with the control. Urease activity was obviously inhibited with the azoxystrobin-treated soil in the first 14 days, but recovered close to the control levels on day 28 . In general, azoxystrobin could cause certain negative effects on soil microbes in the acid soil with low organic matter.
\end{abstract}

Keywords: azoxystrobin, soil viable microbial population, soil enzyme, substrate-induced respiration, soil type

\section{Introduction}

Azoxystrobin, (methyl (E)-2-\{2-[6-(2-cyanophenoxy) pyrimidin-4-yloxy] phenyl\}-3-methoxyacrylate), belongs to a class of novel strobilurin fungicide and can be used to control diseases caused by pathogenic fungi such as ascomycetes, basidiomycetes, oomycete, and imperfect fungi. Because of its broad-spectrum activity,

*e-mail: wfh@sdau.edu.cn

**e-mail: lushzhu@vip.163.com azoxystrobin has been registered for use on 120 crops in more than 100 countries [1]. Since its launch in 1996, azoxystrobin has become the leader in the world fungicide market. Azoxystrobin rang up $\$ 10$ billion in sales in 2010 all over the world, and its consumption was nearly 150 tons in China., Although it has especially become the main fungicide in the European grain market [2-3], adverse effects of the fungicide on soil have appeared [4-7].

Azoxystrobin inhibited mycorrhizal activity [4] and decreased total phylloplane yeast population [8], and disturbed soil fungi structure [9]. However, Bending 
et al. [10] persisted that azoxystrobin had no significant effect on the whole soil fungi community, although it slightly decreased dehydrogenase activity. Azoxystrobin also induced soil urease, dehydrogenases, acid and alkaline phosphatase, and catalase activities [6]. Soil respiration increased with increasing azoxystrobin doses and decreased with increasing incubation time [7]. It obviously decreased the cultivable bacterial, fungal, and actinomycetic populations, soil respiration intensity, protease, and dehydrogenase activities after 7 days of treatment, and inhibited urease activity with $10 \mathrm{mg} \cdot \mathrm{kg}^{-1}$ and stimulated catalase activity with 1.0 and $10 \mathrm{mg} \cdot \mathrm{kg}^{-1}$ of azoxystrobin in black soil [11]. Slightly different from the above results, it decreased soil cultivable microbial numbers, soil respiration, dehydrogenase and protease activities at the beginning of the experiment, and no obvious effects on urease activity and decreased catalase activity were observed in brown soil with azoxystrobin [12]. The differences among the studies were possibly attributed to the differences among soil properties.

Cambisol is widely distributed in hilly areas south of the Yangtze River in China (about $21 \%$ of land area), and azoxystrobin is playing an increasingly important role in controlling diseases of fruits, vegetables, and other crops grown in Cambisol.

Consequently, the aim of the study was to assess the effects of azoxystrobin on microbial population, soil respiration, and enzymatic activities (dehydrogenase, urease, catalase, and protease) in Cambisol with low organic matter and $\mathrm{pH}$.

\section{Materials and Methods}

\section{Chemicals and Reagents}

Azoxystrobin (99\% purity) was purchased from Dr. Ehrenstorfer (Augsburg, Germany). All other chemicals and solvents were AR grade from Sigma Chemical Co., USA, and Shanghai Sangon Biological Engineering Technology and Service Co., Ltd., China.

\section{Soil}

Soil sampling sites were located in Wuyishan city, Fujian Province, China $\left(27.55^{\circ} \mathrm{N}, 118.05^{\circ} \mathrm{E}\right)$. Soil samples were collected in March 2012 from the surface layer $(0-20 \mathrm{~cm})$ of farms, and no pesticides had been applied in the area. Using a 5-point sampling method, the soil samples were taken with a soil sampler, and 5 soil cores ( $8 \mathrm{~cm}$ diameter) were mixed and homogenized to form a composite soil sample (at least $2 \mathrm{~kg}$ ). Soil was classified as Cambisol according to the World Reference Base of Soil Resources. The soil samples were air-dried, ground to pass a $2 \mathrm{~mm}$-mesh screen, and stored at $4^{\circ} \mathrm{C}$ before use. Physicochemical properties of the soil are shown in Table 1.

\section{Experimental Design}

The recommended field dose of azoxystrobin was $5.0 \mathrm{mg} \mathrm{kg} \mathrm{kg}^{-1}$. So, soil samples were treated with azoxystrobin solution (in acetone) to give a final concentration of $0.1,1.0$, and $10.0 \mathrm{mg} \mathrm{kg}^{-1}$ dry soil, representing $1 / 50,1 / 5$, and double the recommended field dose of azoxystrobin, respectively. Non-azoxystrobin soils with an equal volume of pure acetone were used as controls (CK). Soil samples were then put in a fume hood to allow the organic solvent to evaporate. Soil moisture content was kept at $60 \%$ of water-holding capacity (WHC). Soil samples were incubated at $25 \pm 2^{\circ} \mathrm{C}$ in the dark for up to 28 days. Three replicates were tested for all samples. During the experiment, soil moisture was kept unchanged by adding sterile distilled water every 1-2 days. From each mesocosm, $10.00 \mathrm{~g}$ of soil subsample was taken after 7, 14, 21, and 28 days of incubation for determining soil microbial numbers, enzymatic activities, and soil respiration.

\section{Determining Soil Microbial Population}

The plate counting method [13] was applied to measure soil microbial numbers on selective media. Luria-Bertani (LB) medium was used to culture bacterial colonies. Potato dextrose agar (PDA, Difco) supplemented with streptomycin sulphate and sodium penicillin was made for fungi. For actinomycetes, the modified Gaolst medium was applied. $10^{-4}$ of soil suspension was used for bacteria, $10^{-2}$ for fungi, and $10^{-4}$ for actinomycete. Soil suspension of $0.10 \mathrm{~mL}$ was spread on the agar plates and inoculated at $30^{\circ} \mathrm{C}$ for $36 \mathrm{hrs}$ for bacteria, $48 \mathrm{hrs}$ for fungi, and 5 days for actinomycetes. The mean of three replicates was used for statistical analysis.

\section{Soil Respiration Measurements}

Substrate-induced respiration (SIR) was measured with $\mathrm{CO}_{2}$ production. Produced $\mathrm{CO}_{2}$ was treated by $\mathrm{NaOH}$, and the excessive $\mathrm{NaOH}$ reacted with $\mathrm{HCl}(0.2 \mathrm{M})$ $[14,15]$. The respiration activities were recorded as $\mathrm{mg}$ $\mathrm{CO}_{2} \mathrm{~g}^{-1}$ dry soil $\cdot \mathrm{h}^{-1}$.

Table 1. Physico-chemical properties of the soil used in the experiment.

\begin{tabular}{|c|c|c|c|c|c|c|c|c|c|}
\hline Soil type & $\begin{array}{c}\text { Organic } \\
\text { matter } \\
\left(\mathrm{g}^{\mathrm{kg}} \mathrm{gg}^{-1}\right.\end{array}$ & $\begin{array}{c}\text { Available } \\
\text { nitrogen } \\
\left(\mathrm{mg} \cdot \mathrm{kg}^{-1}\right)\end{array}$ & $\begin{array}{c}\text { Available } \\
\text { phosphorus } \\
\left(\mathrm{mg} \cdot \mathrm{kg}^{-1}\right)\end{array}$ & $\begin{array}{c}\text { Available } \\
\text { potassim } \\
\left(\mathrm{mg} \cdot \mathrm{kg}^{-1}\right)\end{array}$ & $\mathrm{pH}$ & $\begin{array}{c}\text { Clay } \\
(<2 \mu \mathrm{m}) \\
(\%)\end{array}$ & $\begin{array}{c}\text { Sand } \\
(>50 \mu \mathrm{m}) \\
(\%)\end{array}$ & $\begin{array}{c}\text { Silt } \\
(50-2 \mu \mathrm{m}) \\
(\%)\end{array}$ & $\begin{array}{c}\text { Maximal } \\
\text { water holding } \\
\text { capacity }(\%)\end{array}$ \\
\hline Cambisols & 9.62 & 44.22 & 8.32 & 66.34 & 5.22 & 17.43 & 44.62 & 37.95 & 20.42 \\
\hline
\end{tabular}




\section{Soil Enzymatic Assays}

Soil dehydrogenase (EC 1.1.1.1) and urease (EC 3.5.1.5) activities were measured according to Kong et al. [16], with 2, 3, 5-triphenyltetrazolium chloride (TTC) and urea as the substrates, respectively. The soluble TTC can be reduced into red compound triphenylformazan (TPF) and its color intensity was measured at $485 \mathrm{~nm}$ using a spectrophotometer (Shimadzu UV-2550, Japan). The results were recorded as mg TPF $\cdot \mathrm{kg}^{-1} \mathrm{dry}$ soil. Soil urease activity was expressed in terms of ug $\mathrm{NH}_{4}^{+} \cdot \mathrm{g}^{-1}$ dry soil. Catalase (EC 1.11.1.6) activity was measured according to the previous study [17], with $\mathrm{H}_{2} \mathrm{O}_{2}$ as the substrate. The results were expressed as $\mathrm{mL} 0.02 \mathrm{M}$ $\mathrm{KMnO}_{4} \cdot \mathrm{g}^{-1}$ dry soil. Soil protease activity was measured based on the previous method [13], the results were expressed as tyrosine $\mathrm{mg} \cdot \mathrm{g}^{-1}$ soil.

\section{Statistical Analysis}

All the data were expressed in terms of the mean \pm the standard deviation (SD). The statistical analyses were conducted using SPSS software (Version 19.0, SPSS Inc.). One-way analysis of variance (ANOVA) was performed to assess statistically significant differences between the mean values with the least significant difference (LSD) test. At the same time, bi-factorial analysis of variance (ANOVA) was performed to assess the significance of differences according to the application dosage, incubation time, and their interaction with a post-hoc test and the least significant difference (LSD) test. Correlation analysis among soil cultivable microbial numbers, soil respiration, and soil enzymatic activities were done using SPSS statistical software. A value of $p<0.05$ was considered as significant.

\section{Results and Discussion}

\section{Effects of Azoxystrobin on Soil Cultivable Microbial Numbers}

The plate-count data indicated that azoxystrobin affected the numbers of culturable bacteria and actinomycetes to a small extent, but not those of fungi (Fig. 1). Soil bacteria and actinomycete population in azoxystrobin-treated soils were not significantly different $(p>0.05)$ from the controls on days 7 and 14 , with the exception of $10 \mathrm{mg} \cdot \mathrm{kg}^{-1}$ of azoxystrobin on day 14 . Bacterial and actinomycetes populations significantly decreased with increasing concentrations of azoxystrobin on days 21 and 28, as indicated by negative correlation coefficients ( -0.92 and -0.86 for bacteria on days 21 and $28,-0.83$ and -0.90 for actinomycetes on days 21 and 28, respectively), with the exception of $1.0 \mathrm{mg} \cdot \mathrm{kg}^{-1}$ for the azoxystrobin group. However, no significant differences $(p>0.05)$ could be found in respect to fungi populations among different concentrations of treatments. The decreasing trend of cultivable microbial numbers indicated that azoxystrobin have toxic effects on soil bacteria and actinomycetes.

Soil cultivable microbial population is directly related to soil organic matter decomposition and transformation of mineral elements. So, it is critical to investigate the impacts of azoxystrobin on soil cultivable microorganisms to better understand the effects of azoxystrobin on soil quality and fertility. Studies have shown that effects of fungicides on the soil microbial population depend on the structures of fungicides, i.e., different mechanisms against pathogens [18], applied doses [19-20], and types of soils [10], etc. So impacts of fungicides with different structures on soil microbial populations are not easily predicted [18]. Although our results were in accord
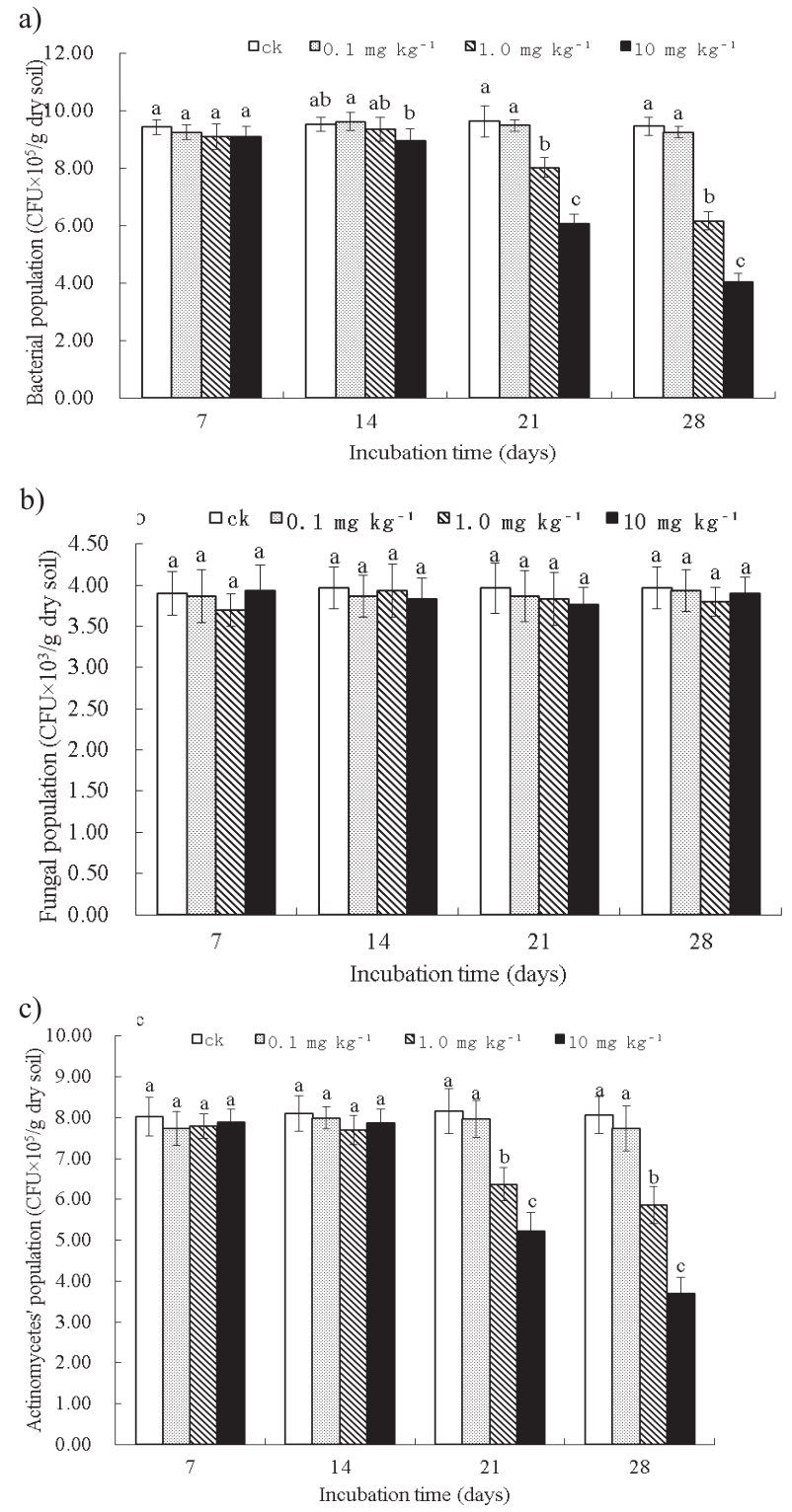

Fig. 1. Effects of azoxystrobin on the numbers of bacteria a), fungi b), and actinomycete c) in red soil; error bars represent the standard deviation (S.D), and different letters above the bars indicate significant differences compared to the controls at $p<0.05$ level. 
with those of butachlor [21] and Funaben T [22], high concentrations of mefenoxam significantly increased bacteria populations [23]. Soil bacteria, fungi, and actinomycete were all inhibited by Azoxystrobin [11-12]. In this study, although soil bacterial and actinomycete numbers were drastically depressed, no significant effects on fungal population were also observed. This may be due to the lower $\mathrm{pH}$ value of the soil $(\mathrm{pH}=5.22)$, which promotes fungal growth [24]. So, the responses of soil microbial communities to fungicides were dependent on soil characteristics.

\section{Effect of Azoxystrobin on Soil Respiration}

In the first 14 days of incubation, there were no dramatic differences among treated and untreated samples, but soil respiration reduced in $1.0 \mathrm{mg} \cdot \mathrm{kg}^{-1}$ and $10.0 \mathrm{mg} \cdot \mathrm{kg}^{-1}$ of azoxystrobin-treated soils compared with the controls on days 21 and day 28, and significantly negatively correlated with the dose of azoxystrobin $(p<0.01)$, with the coefficient of correlation -0.75 and -0.87 (Fig. 2). At the end of the experiment, soil respiration decreased by $16.6 \%$ and $29.4 \%$ for $1.0 \mathrm{mg} \cdot \mathrm{kg}^{-1}$ and $10.0 \mathrm{mg} \cdot \mathrm{kg}^{-1}$ of azoxystrobin, respectively. In general, the fungicide azoxystrobin inhibited soil respiration.

Soil respiration is often used to indicate metabolic activity of soil microbes [25]. In addition, it represents one of the largest sources of $\mathrm{CO}_{2}$ returning from soil to the atmosphere. Therefore, to better understand the carbon (C) cycle of terrestrial ecosystems, it is of very important significance to study responses of soil respiration to the application of fungicides [26]. Similarly, there has been much research of inhibitory effects on soil respiration [27-30]. On the contrary, soil respiration was stimulated by pyrimorph application [31], and low concentrations of mancozeb and dinocap [32]. Above all, different fungicides have various effects on soil respiration. Even in different types of soils the inhibition of soil respiration were also observed in treatments with azoxystrobin [1112], which indicated that soil types did not influence the responses of soil respiration to azoxystrobin.

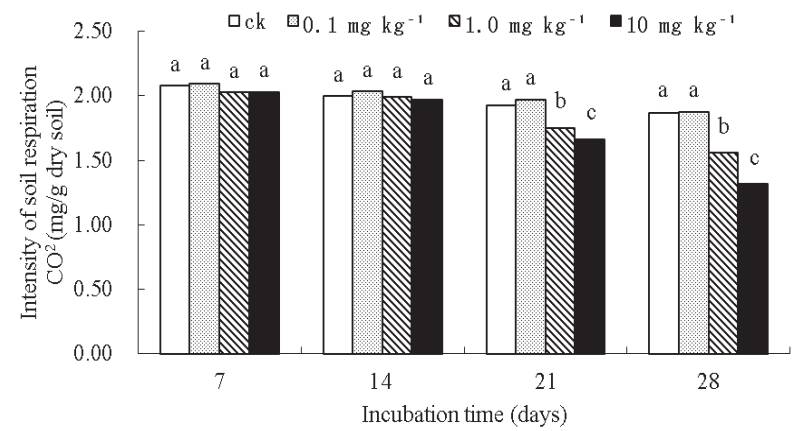

Fig. 2. Effects of azoxystrobin on soil respiration; error bars represent standard deviation (S.D), and different letters above the bars indicate significant differences compared to the controls at $p<0.05$ level.

\section{Effects of Azoxystrobin on Dehydrogenase Activity}

Dehydrogenase showed a significant decrease $(p<0.05)$ with the addition of azoxystrobin to soils with the exception of day 7 (Fig. 3a). Also, the dehydrogenase activity was significantly negatively correlated with concentrations of azoxystrobin, as indicated by values of correlation coefficients $(-0.87,-0.77$, and -0.80 on days 14,21 , and 28 , respectively). At the end of incubation, dehydrogenase activity declined by $19.1 \%, 49.8 \%$, and $69.4 \%$ for $0.1,1.0$, and $10.0 \mathrm{mg} \cdot \mathrm{kg}^{-1}$ of azoxystrobin compared with the controls. In conclusion, azoxystrobin had an obviously adverse impact on soil dehydrogenase activity.

Dehydrogenase activity has been considered an important indicator of the whole soil microbial activity, so it has been commonly used to assess the side effects of agricultural chemicals [33-34]. Similarly, the application of mefenoxam and metalaxyl [23], benomyl, captan [27], carbendazim [35], mancozeb, and dimethomorph [19] also posed a threat to soil dehydrogenase activity to different degrees. However, Sukul [36] and Tejada et al. [37] observed initially increased and then decreased dehydrogenase activity treated with fungicide. In contrast to the above, no significantly stimulated or inhibited effects were observed in dehydrogenase activity polluted by tebuconazole [29]. Although dehydrogenase activities were all reduced, incubation time point causing decrease and inhibitory degree were different from this [11-12]. Similarly, Bending et al. [10] discovered that all fungicides (chlorothalonil, azoxystrobin, and tebuconazole) obviously decreased dehydrogenase activity to different degrees in the low OM/biomass soil, but not in the high OM/biomass soil. The above results indicated that the extent of influence on dehydrogenase activity of fungicides was correlated with the soil types. In addition, dehydrogenases catalyze the oxido-reductive processes by removing two hydrogen atoms from the substrates, which is closely related to populations of the active microorganisms [38], as indicated by the significant positive correlation with populations of bacteria and actinomycetes (Table 4). In our study, bacteria and actinomycetes were inhibited, and consequently dehydrogenases are also reduced.

\section{Effects of Azoxystrobin on Urease Activity}

The results of urease activities (Fig. 3b) were not in agreement with those of dehydrogenase activities. The addition of azoxystrobin immediately had a distinct inhibition effect on urease activity, and urease activity significantly correlated negatively with the concentrations of azoxystrobin, with the coefficient of correlation of -0.54 on day 7 and -0.80 on day 14 . After 14 days, urease activity gradually increased and that in the $0.1 \mathrm{mg} \cdot \mathrm{kg}^{-1}$ group recovered to the control level on day 21. At the end of the incubation period, urease activities 
a)

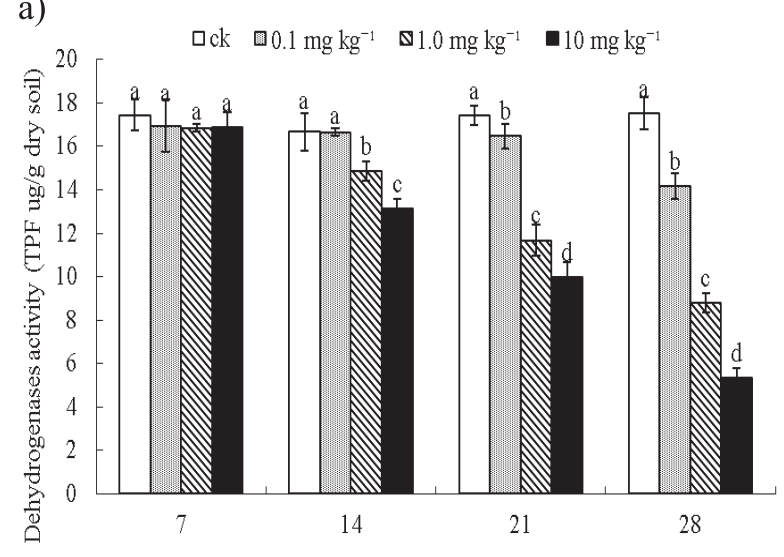

b)

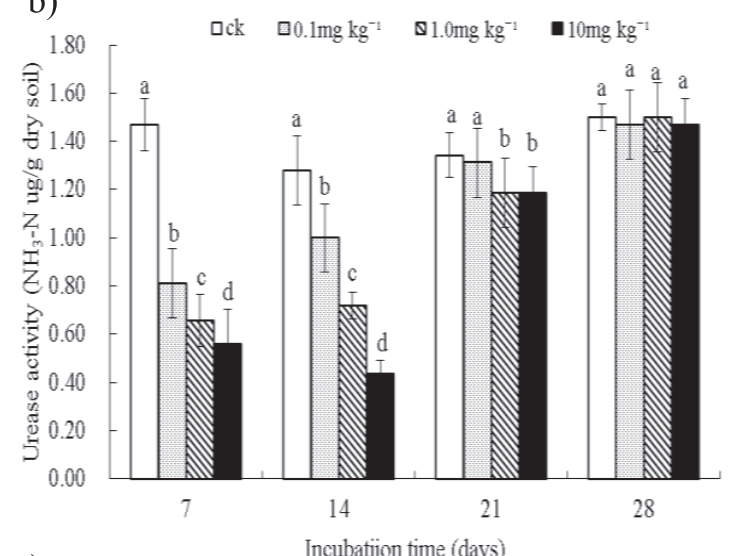

c)

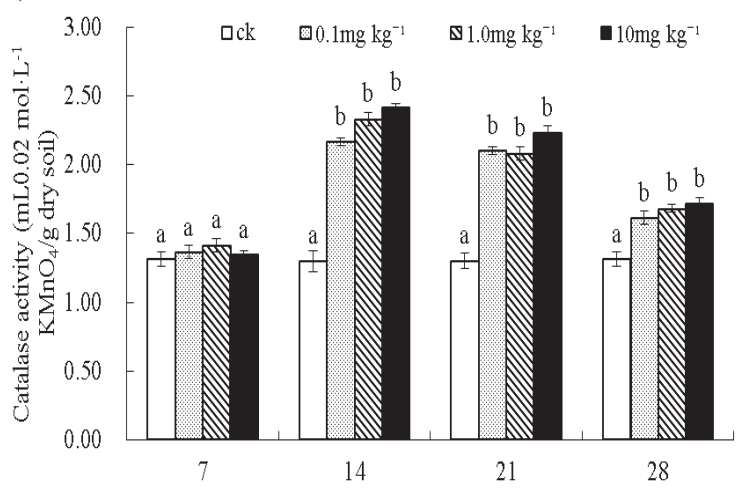

d)

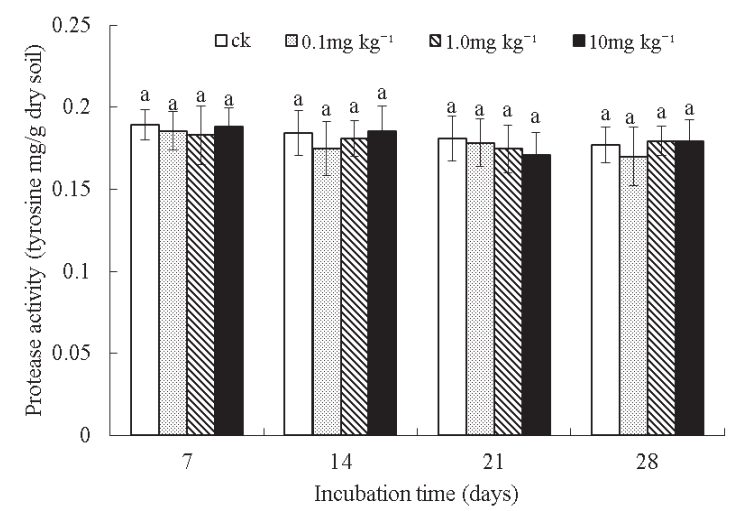

Fig. 3. Effects of azoxystrobin on dehydrogenase activity a), urease activity b), catalase activity c), and protease activity d) in red soil; error bars represent standard deviation (S.D), and different letters above the bars indicate significant differences compared to the controls at $p<0.05$ level. in treated samples all recovered to the control level. That is, significant differences did not exist between treatments and controls $(p>0.05)$. In conclusion, azoxystrobin had a transient inhibitory effect on soil urease activity.

Different from our result, pyrimorph at the lowest dose $\left(0.5 \mathrm{mg} \cdot \mathrm{kg}^{-1}\right)$ had no apparent impact on urease activity. However, in doses from 5.0 to $150.0 \mathrm{mg} \cdot \mathrm{kg}^{-1}$, pyrimorph posed a stimulation effect on urease activities in the first 60 days, followed by an inhibition effect at the end of the experiment [31]. Prochloraz [37], carbendazim [39], and benomyl and captan [27] had a stimulating effect on soil urease activity. On the contrary, Cycoń et al. [19] and Muňoz-Leoz et al. [29] reported declines in urease activity in soils treated with mancozeb, dimethomorph, and tebuconazole compared with the controls. A sharp decrease in urease shortly after the azoxystrobin addition resulted from the toxicity of azoxystrobin. It was interesting that there were significant different responses of urease activity in azoxystrobintreated soils with different properties. Azoxystrobin had no effect on urease activity in loam soil [12], but the fungicide in black soil inhibited urease activity only in the $10.0 \mathrm{mg} \cdot \mathrm{kg}^{-1}$ concentration group on days 14,21 , and 28 [11], and in sandy loam with a $\mathrm{pH} 7.0$ from 0.075 to $22.50 \mathrm{mg} \mathrm{kg}^{-1}$ [6]. This revealed that the responses of urease activity to fungicide depend on soil types. High urease activities are related to high organic matter content [40], and $80 \%$ of soil urease activity was extracellular and complexed by soil colloids [41]. The contents of soil colloids were different in the three soils, which resulted in urease being exposed to azoxystrobin to different degrees, that is, the different toxic effects.

\section{Effects of Azoxystrobin on Catalase Activity}

As shown in Fig. 3c), the values obtained in soil catalase activity indicated variable behavior during the experimental period. Unlike dehydrogenase activity, although there were no changes in catalase activity among treated and untreated soils over 7 days of incubation, catalase activity increased significantly on days 14, 21, and 28 , and no significant differences $(p>0.05)$ were observed among treatments at the same time. The results suggested that azoxystrobin stimulated catalase activity in soils.

Similar to results in this research, an apparent increase in catalase activity and then a recovery in azoxystrobin-treated loam soil, and no clear effect within 21 days and then an apparent increase at the end of the incubation in black soil with the fungicide were reported [11-12]. Catalase activity fluctuated sharply during the incubation period in pyrimorph-treated soils, but increased catalase activity at the end of the incubation was observed [31]. Different from our study, Baćmaga et al. [6] reported the inhibited catalase activities. No changes in catalase activity on day 7 revealed that catalase activity was not sensitive to azoxystrobin. 
The stimulated effect was decreased upon further incubation due to the degradation of azoxystrobin and decline of concentration. The results of increased catalase activity at the end of the incubation period compared to the controls were due to the stress on microorganisms [39]. Catalase, as an oxidoreductase, is a kind of intracellular enzyme [42]. The stimulated catalase activity reflected cellular damage and stimulation of the antioxidant mechanism for protecting the treated cells. The addition of azoxystrobin changed the soil ecosystem with increasing concentrations in soil. In response to the changed soil environment, microorganisms increased their metabolic activity [43].

\section{Effects of Azoxystrobin on Protease Activity}

The values obtained from protease activity (Fig. 3d) treated with azoxystrobin were contrary to the catalase activity. After the application of azoxystrobin to the soil, protease activity had no significant $(p>0.05)$ decrease or increase tendency compared with the control. That is, neither the concentration nor the incubation time influenced the changes of soil protease activity. It is apparent that azoxystrobin had no impact on soil protease activity.

Protease belongs to an important class of hydrolytic enzymes used for proteins hydrolysis and production of amino acid [44]. There are few studies on the impact of fungicide on soil protease activity. Different from our results, pentachlorophenol had dramatically reduced protease in soils [45]. Two organophosphorus insecticides and 2 synthetic pyrethroids raised protease activity in the field [46]. In our experiments, protease activities of the treatments were always close to the control during the incubation, which indicated that protease was insensitive to azoxystrobin. It is noted that the persistent inhibitory effect in loam soil and hysteretic depression in black soil were strongly different

Table 2. ANOVA results for biochemical responses of soil microorganism and enzymatic activities to azoxystrobin in red soil.

\begin{tabular}{|c|c|c|c|c|c|c|c|c|c|}
\hline \multirow{2}{*}{ Biomarkers } & \multicolumn{3}{|c|}{ Dose } & \multicolumn{3}{c|}{ Time } & \multicolumn{3}{c|}{ Dose*Time } \\
\cline { 2 - 10 } & $\mathrm{df}$ & $\mathrm{F}$ & $\mathrm{p}$ & $\mathrm{df}$ & $\mathrm{F}$ & $\mathrm{p}$ & $\mathrm{df}$ & $\mathrm{F}$ & $\mathrm{p}$ \\
\hline Bacteria population & 3 & 141.815 & $0.000^{*}$ & 3 & 101.091 & $0.000^{*}$ & 9 & 36.502 & $0.000^{*}$ \\
\hline Fungi population & 3 & 0.530 & 0.665 & 3 & 0.121 & 0.947 & 9 & 0.200 & 0.992 \\
\hline Actinomycete population & 3 & 52.961 & $0.000^{*}$ & 3 & 39.360 & $0.000^{*}$ & 9 & 16.446 & $0.000^{*}$ \\
\hline Soil respiration & 3 & 46.214 & $0.000^{*}$ & 3 & 106.661 & $0.000^{*}$ & 9 & 10.909 & $0.000^{*}$ \\
\hline Dehydrogenase activity & 3 & 219.271 & $0.000^{*}$ & 3 & 163.486 & $0.000^{*}$ & 9 & 39.237 & $0.000^{*}$ \\
\hline Urease activity & 3 & 36.868 & $0.000^{*}$ & 3 & 78.338 & $0.000^{*}$ & 9 & 9.152 & $0.000^{*}$ \\
\hline Protease activity & 3 & 0.379 & 0.768 & 3 & 1.505 & 0.232 & 9 & 0.248 & 0.984 \\
\hline Catalase activity & 3 & 440.271 & $0.000^{*}$ & 3 & 544.328 & $0.000^{*}$ & 9 & 67.165 & $0.000^{*}$ \\
\hline
\end{tabular}

*Indicates a significant effect of azoxystrobin concentration, time of exposure, and their interaction on biochemical responses $(\mathrm{p}<0.05)$

Table 3. Results of post-hoc test by LSD after bi-factorial ANOVA for biochemical responses of soil microorganism and enzymatic activities to azoxystrobin in red soil.

\begin{tabular}{|c|c|c|c|c|c|c|c|c|}
\hline \multirow{2}{*}{ Biomarkers } & \multicolumn{4}{|c|}{ Dose $\left(\mathrm{mg} \cdot \mathrm{kg}^{-1}\right)$} & \multicolumn{4}{|c|}{ Time (day) } \\
\hline & 0 & 0.1 & 1.0 & 10 & 7 & 14 & 21 & 28 \\
\hline Bacteria population & $\mathrm{a}$ & $\mathrm{a}$ & $\mathrm{b}$ & $\mathrm{c}$ & $\mathrm{a}$ & $\mathrm{a}$ & $\mathrm{b}$ & $\mathrm{c}$ \\
\hline Fungi population & $\mathrm{a}$ & $\mathrm{a}$ & $\mathrm{a}$ & $\mathrm{a}$ & a & $\mathrm{a}$ & $\mathrm{a}$ & $\mathrm{a}$ \\
\hline Actinomycete population & $\mathrm{a}$ & $\mathrm{a}$ & $\mathrm{b}$ & $\mathrm{c}$ & a & $\mathrm{a}$ & $\mathrm{b}$ & c \\
\hline Soil respiration & $\mathrm{a}$ & $\mathrm{a}$ & $\mathrm{b}$ & $\mathrm{c}$ & $\mathrm{a}$ & $\mathrm{b}$ & $\mathrm{c}$ & $\mathrm{d}$ \\
\hline Dehydrogenase activity & $\mathrm{a}$ & $\mathrm{b}$ & $\mathrm{c}$ & $\mathrm{d}$ & $\mathrm{a}$ & $\mathrm{b}$ & $\mathrm{c}$ & d \\
\hline Urease activity & $\mathrm{a}$ & $\mathrm{b}$ & $\mathrm{c}$ & $\mathrm{d}$ & $\mathrm{a}$ & $\mathrm{a}$ & $\mathrm{b}$ & $\mathrm{c}$ \\
\hline Protease activity & $\mathrm{a}$ & $\mathrm{a}$ & $\mathrm{a}$ & $\mathrm{a}$ & $\mathrm{a}$ & $\mathrm{a}$ & $\mathrm{a}$ & $\mathrm{a}$ \\
\hline Catalase activity & $\mathrm{a}$ & $\mathrm{b}$ & $\mathrm{c}$ & $\mathrm{d}$ & $\mathrm{a}$ & $\mathrm{b}$ & $\mathrm{c}$ & $\mathrm{d}$ \\
\hline
\end{tabular}


from the results in the present study [11-12]. That is, the responses of protease activity to fungicide depend on soil type. The organic matter $\left(9.62 \mathrm{~g} \mathrm{~kg}^{-1}\right)$ was lower than in the previous studies $\left(13.91 \mathrm{~g} \mathrm{~kg}^{-1}\right.$ in loam soil and $26.54 \mathrm{~g} \mathrm{~kg}^{-1}$ in black soil, respectively), which resulted in lower protease activity [11-12]. The finding was in agreement with that of Mäder et al. [47], that is, a higher capacity to cleave protein was in soils of the organic systems.

\section{Bi-Factorial ANOVA Results of Microbial Populations and Soil Biochemical Properties}

Effects of incubation time (7, 14, 21, and 28 days), concentration $\left(0.1,1.0\right.$, and $\left.10 \mathrm{mg} \cdot \mathrm{kg}^{-1}\right)$, and their interaction on soil microbial populations and biochemical properties are shown in Tables 2-3. Time, dosage, and their interaction all had a significant effect on the populations of bacteria and actinomycetes, respiration intensity, dehydrogenase activity, urease activity, and catalase activity. However, neither the above 2 factors respectively nor their interaction affected fungi population and protease activity. Additionally, the post-hoc test results revealed that the changes in the exposure concentration could significantly influence dehydrogenase, urease, and catalase activities. Also, the changes of incubation time dramatically impacted soil respiration, dehydrogenase, and catalase activities (Table 3). That is, dehydrogenase, urease and catalase activities were obviously different in each treatment group. However, no distinct discrepancy could be observed in the fungi population and protease activity at each incubation time point and each exposure dosage in azoxystrobin-treated soils. Slightly from the results, doses and the interaction of doses and time did not significantly affect the responses of soil respiration to glyphosate, suggesting the main roles of the pollutant $[20,48]$.

\section{Correlation Among Soil Cultivable Microbial Numbers, Soil Respiration, and Soil Enzymatic Activities}

As were expected (Table 4), the bacteria population was significantly correlated positively with the actinomycetes population, soil respiration, and dehydrogenase activity. At the same time, dramatically negative correlations between soil respiration and urease activity, dehydrogenase activity and catalase activity, and urease activity and catalase activity were also observed. Only the fungi population and protease activity were not associated with any other parameters of the soil. Correlation among soil cultivable microbial numbers, soil respiration, and soil enzymatic activities were reflected by the differences of impacts of azoxystrobin on soil cultivable microbial numbers, soil respiration, and soil enzymatic activities. Soil respiration and dehydrogenase activity were indicators of the whole microbial activities, so they were positively correlated with the bacteria and actinomycete population. The other three enzymes represented different activities respectively, so they did not correlate with each other positively.

\section{Conclusions}

Our results indicate that azoxystrobin inhibited soil respiration, the populations of bacteria and actinomycetes, and dehydrogenase activity. However, azoxystrobin did not exert an obvious effect on fungi population and protease activity. Urease activity was reduced significantly with azoxystrobin treatments transiently, and the inhibitory effect faded away and returned to the control level in the end. Among the soil properties studied, dehydrogenase activity is the most sensitive to azoxystrobin in Cambisol. The results help us better understand the effects of azoxystrobin

Table 4. Correlation analysis among soil cultivable microbial numbers, soil respiration, and soil enzymatic activities in red soil.

\begin{tabular}{|c|c|c|c|c|c|c|c|c|}
\hline & $\begin{array}{c}\text { Bacteria } \\
\text { population }\end{array}$ & $\begin{array}{c}\text { Fungi } \\
\text { population }\end{array}$ & $\begin{array}{c}\text { Actinomycete } \\
\text { population }\end{array}$ & $\begin{array}{c}\text { Soil } \\
\text { respiration }\end{array}$ & $\begin{array}{c}\text { Dehydrogenase } \\
\text { activity }\end{array}$ & $\begin{array}{l}\text { Urease } \\
\text { activity }\end{array}$ & $\begin{array}{l}\text { Protease } \\
\text { activity }\end{array}$ & $\begin{array}{l}\text { Catalase } \\
\text { activity }\end{array}$ \\
\hline Bacteria population & 1 & & & & & & & \\
\hline Fungi population & 0.122 & 1 & & & & & & \\
\hline Actinomycete population & $0.934^{* *}$ & 0.123 & 1 & & & & & \\
\hline Soil respiration & $0.907^{* *}$ & 0.078 & $0.873^{* *}$ & 1 & & & & \\
\hline Dehydrogenase activity & $0.921^{* *}$ & 0.145 & $0.910^{* *}$ & $0.903^{* *}$ & 1 & & & \\
\hline Urease activity & -0.276 & 0.186 & -0.261 & $-0.464^{* *}$ & -0.239 & 1 & & \\
\hline Protease activity & 0.105 & -0.092 & 0.141 & 0.123 & 0.150 & -0.139 & 1 & \\
\hline Catalase activity & -0.193 & -0.098 & -0.241 & -0.179 & $-0.382^{* *}$ & $-0.291^{*}$ & -0.173 & 1 \\
\hline
\end{tabular}

Notes: The correlation was at $95 \%$ confidence interval (alpha $=0.05)$

** means correlation is significant at the 0.01 level (2-tailed)

* means correlation is significant at the 0.05 level (2-tailed) 
on soil biochemical properties in soil with low $\mathrm{pH}$ and organic matter content. The diverse effects of azoxystrobin on soil quality suggest that azoxystrobin should be used following the manufacturer's recommended doses.

\section{Acknowledgements}

The present study was supported by the National Key Research and Development Plan (grant No. 2016YFD0800202), grants from the National Natural Science Foundation of China (Nos. 41771282 and 41701279), the Specialized Research Fund for the Doctoral Program of Higher Education (No. 20113702110007) and China Postdoctoral Science Foundation (2016M602168).

\section{References}

1. BAI Y.L. The progresses of research and development on strobilurin fungicides. Agrochemicals. 46, 289, 2007.

2. SUN T.S., SHEN Z.X., The market status and development analysis of azoxystrobin. Guangdong. Chem. Eng. 40 (2), 60, 2013.

3. ZHANG Y.B. Analysis of pesticide products of sales of hundreds of millions of dollars in recent years. J. AgrochemChina. 21 (43), 48, 2011.

4. DIEDHIOU P.M., OERKE E.C., DEHNE H.W. Effects of the strobilurin fungicides azoxystrobin and kresoximmethyl on arbuscular mycorrhiza. Z. Pflanzenk. Pflanzen. 111 (6), 54, 2004.

5. VILLENEUVE A., MONTUELLE B., BOUCHEZA A. Effects of flow regime and pesticides on periphytic communities: evolution and role of biodiversity. Aquat. Toxicol. 102 (3-4), 123, 2011.

6. BAĆMAGA M., KUCHARSKI J., WYSZKOWSKA J. Microbial and enzymatic activity of soil contaminated with azoxystrobin. Environ. Monit. Assess. 187 (10), 615, 2015.

7. ÁLVAREZ-MARTÍN A., HILTON S.L., BENDING G.D., RODRÍGUEZ-CRUZ M.S., SÁNCHEZ-MARTÍN M.J. Changes in activity and structure of the soil microbial community after application of azoxystrobin or pirimicarb and an organic amendment to an agricultural soil. Appl. Soil. Ecol. 106, 47, 2016.

8. BUCK J.W., BURPEE L.L. The effects of fungicides on the phylloplane yeast populations of creeping bentgrass. Can. J. Microbiol. 48 (6), 522, 2002.

9. ADETUTU E.M., BALLAND A.S., OSBORN A.M. Azoxystrobin and soil interactions: degradation and impact on soil bacterial and fungal communities. J. Appl. Microbiol. 105 (6), 1777, 2008.

10. BENDING G.D., RODRIGUEZ-CRUZ M.S., LINCOLN S.D. Fungicide impacts on microbial communities in soils with contrasting management histories. Chemosphere. 69 (1), 82, 2007.

11. GUO P., ZHU L., WANG J., WANG J., XIE H., LV D. Enzymatic activities and microbial biomass in black soil as affected by azoxystrobin. Environ. Earth. Sci. 74 (2), 1, 2015.

12. WANG F.H., ZHU L.S., LV D.D., GUO P.P., WANG J., WANG J.H. Effects of azoxystrobin on soil microorganisms and enzymatic activities. Fresen. Environ. Bull. 24 (10a), 3336, 2015.
13. ZHANG Q.M., ZHU L.S., WANG J., XIE H., WANG J.H., WANG F.H., SUN F.X. Effects of fomesafen on soil enzyme activity, microbial population, and bacterial community composition. Environ. Monit. Assess. 186, 2801, 2014.

14. RUTIGLIANO F.A., ROMANO M., MERZAIOLI R., BAGLIVO I., BARONTI S., MIGLIETTA F., CASTALDI S. Effect of biochar addition on soil microbial community in a wheat crop. Eur. J. Soil Biol, 60, 9, 2014.

15. GE G.F., LI Z.J., ZHANG J., WANG L.G., XU M.G., ZHANG J.B., WANG J.K., XIE X.L. LIANG Y.C. Geographical and climatic differences in long-term effect of organic and inorganic amendments on soil enzymatic activities and respiration in field experimental stations of China. Ecol. Complex. 6, 421, 2009.

16. KONG L.F., ZHU S.Y., ZHU L.S., XIE H., WEI K., YAN T.X., WANG J., WANG J.H., WANG F.H., SUN F.X. Colonization of Alcaligenes faecalis strain JBW4 in natural soils and its detoxification of endosulfan. Appl. Microbiol. Biot. 98 (3), 1407, 2014.

17. STEPNIEWSKAZ., WOLINSKA A., ZIOMEK J. Response of soil catalase activity to chromium contamination. J. Environ. Sci-China. 21 (8), 1142, 2009.

18. ABBOUD M.A.A. Bioimpact of application of pesticides with plant growth hormone (gibberellic acid) on target and non-target microorganisms. J. Saudi. Chem. Soc. 18 (6), 1005, 2014.

19. CYCOŃ M., PIOTROWSKA-SEGET Z., KOZDROJ J. Responses of indigenous microorganisms to a fungicidal mixture of mancozeb and dimethomorph added to sandy soils. Int. Biodeter. Biodegr. 64 (4), 316, 2010.

20. BENNICELLI R.P., SZAFRANEK-NAKONIECZNA A., WOLIŃSKA A., STĘPNIEWSKA Z., BOGUDZIŃSKA $M$. Influence of pesticide (glyphosate) on dehydrogenase activity, $\mathrm{pH}$, Eh and gases production in soil (laboratory conditions). Int. Agrophys. 23 (2), 117, 2009.

21. YEN J.H., WANG Y.S., HSU W.S., CHEN W.C. Phylogenetic changes in soil microbial and diazotrophic diversity with application of butachlor. J. Environ. Sci. Heal. B. 48 (1), 49, 2013.

22. NIEWIADOMSKA A., SAWICKA A. Effect of carbendazim, imazetapir and thiram on nitrogenase activity, number of microorganisms in soil and yield of hybrid lucerne (medicago media). Pol. J. Environ. Stud. 11 (6), 737, 2002.

23. MONKIEDJE A., ILORI M.O., SPITELLER M. Soil quality changes resulting from the application of the fungicides mefenoxam and metalaxyl to a sandy loam soil. Soil. Biol. Biochem. 34 (12), 1939, 2002.

24. SULOWICZ S., PIOTROWSKA-SEGET Z. Response of microbial communities from an apple orchard and grassland soils to the first-time application of the fungicide tetraconazole. Ecotox. Environ. Safe. 124, 193, 2016.

25. WOLIŃSKA A., STĘPIEWSKA Z., SZAFRANEKNAKONIECZNA A. Effect of selected physical parameters on respiration activities in common Polish mineral soils. Pol. J. Environ. Stud. 20 (4), 1075, 2011.

26. ZHU J., KANG F., CHEN J., CHENG X., HAN H. Effect of nitrogen addition on soil respiration in a larch plantation. Pol. J. Environ. Stud. 26 (3), 1403, 2017.

27. CHEN S.K., EDWARDS C.A., SUBLER S. A microcosm approach for evaluating the effects of the fungicides benomyl and captan on soil ecological processes and plant growth. Appl. Soil. Ecol. 18 (1), 69, 2001.

28. CHEN S.K., EDWARDS C.A., SUBLER S. Effects of the fungicides benomyl, captan and chlorothalonil on soil 
microbial activity and nitrogen dynamics in laboratory incubations. Soil. Biol. Biochem. 33 (14), 1971, 2001.

29. MUÑOZ-LEOZ B., RUIZ-ROMERA E., ANTIGÜEDAD I., GARBISU C. Tebuconazole application decreases soil microbial biomass and activity. Soil. Biol. Biochem. 43 (10), 2176, 2011

30. STEFANI A., FELÍCIO J.D., ANDRÉA M.M.D. Comparative assessment of the effect of synthetic and natural fungicides on soil respiration. Sensors. 12 (3), 3243, 2012.

31. XIONG D., GAO Z.Z., FU B., SUN H., TIAN S.L., XIAO Y.M., QIN Z.H. Effect of pyrimorph on soil enzymatic activities and respiration. Eur. J. Soil. Biol. 56 (3), 44, 2013.

32. ČERNOHL ÁVKOVÁ J., JARKOVSKOYÝ J., HOFMAN J. Effects of fungicides mancozeb and dinocap on carbon and nitrogen mineralization in soils. Ecotox. Environ. Safe. 72 (1), 80, 2009.

33. CYCOŃ M., PIOTROWSKA-SEGET Z. KOZDRÓ J. Dehydrogenase activity as an indicator of different microbial responses to pesticide-treated soils. Chem. Ecol. 26 (4), 243, 2010.

34. WOLIŃSKA A., BENNICELLI R.P. Dehydrogenase activity response to soil reoxidation process described as varied conditions of water potential, air porosity and oxygen availability. Pol. J. Environ. Stud. 19 (3), 651, 2010.

35. BURROWS L.A., EDWARDS C.A. The use of integrated soil microcosms to assess the impact of carbendazim on soil ecosystems. Ecotoxicology. 13 (1-2), 143, 2004.

36. SUKUL P. Enzymatic activities and microbial biomass in soil as influenced by metalaxyl residues. Soil. Biol. Biochem. 38 (2), 320, 2006.

37. TEJADA M., GÓMEZ I., GARCÍA-MARTÍNEZ A.M., OSTA P., PARRADO J. Effects of Prochloraz fungicide on soil enzymatic activities and bacterial communities. Ecotox. Environ. Safe. 74 (6), 1708, 2011.

38. GAŁAZKA A., GAWYJOŁEK K., PERZYŃSKI A., GAŁAZKA R., KSIĘAK J. Changes in Enzymatic Activities and microbial communities in soil under longterm maize monoculture and crop rotation. Pol. J. Environ. Stud. 26(1), 39, 2017.
39. YAN H., WANG D.D., DONG B., TANG F.F., WANG B.C., FANG H., YU Y.L. Dissipation of carbendazim and chloramphenicol alone and in combination and their effects on soil fungal:bacterial ratios and soil enzyme activities. Chemosphere. 84 (5), 634, 2011.

40. ANURADHAB., REKHAPADMINIA., RANGASWAMY $\mathrm{V}$. Influence of tebuconazole and copper hydroxide on phosphatase and urease activities in red sandy loam and black clay soils. 3 Biotech. 6 (1), 78, 2016.

41. LI Z.Y., JIN Z.J., LI Q. Changes in Land Use and their Effects on soil properties in huixian karst wetland system. Pol. J. Environ. Stud. 26 (2), 699, 2017.

42. KHAN S., CAO Q., HESHAM A.E., XIA Y., HE J.Z. Soil enzymatic activities and microbial community structure with different application rates of $\mathrm{Cd}$ and $\mathrm{Pb}$. J Environ. Sci-China. 19 (7), 834, 2007.

43. TEJADA M. Evolution of soil biological properties after addition of glyphosate, diflufenican and glyphosate+diflufenican herbicides. Chemosphere. 76, 365, 2009.

44. GEISSELER D., HORWATH W.R., JOERGENSEN R.G., LUDWIG B. Pathways of nitrogen utilization by soil microorganisms-a review. Soil. Biol. Biochem. 42 (12), 2058, 2010.

45. WU W.X., YE Q.F., MIN H. Effect of straws from Bt-transgenic rice on selected biological activities in water-flooded soil. Eur. J. Soil. Biol. 40 (1), 15, 2004.

46. RANGASWAMY V., REDDY B.R., VENKATESWARLU $\mathrm{K}$. Activities of dehydrogenase and protease in soil as influenced by monocrotophos, quinalphos, cypermethrin and fenvalerate. Agr. Ecosyst. Environ. 47 (4), 319, 1994.

47. MÄDER P., FLIESSBACH A., DUBOIS D., GUNST L., FRIED P., NIGGLI U. Soil fertility and biodiversity in organic farming. Science. 296 (5573), 1694, 2002.

48. GOMEZ E., FERRERAS L., LOVOTTI L., FERNANDEZ E. Impact of glyphosate application on microbial biomass and metabolic activity in a Vertic Argiudoll from Argentina. Eur. J. soil. Biol. 45 (2), 163, 2009. 
